\title{
World Cinema in a Global Frame
}

\author{
Seung-hoon Jeong \\ Film and Electronic Arts, California State University Long Beach, \\ Long Beach, California, USA \\ seunghoon.jeong@csulb.edu
}

\begin{abstract}
The "world" in film studies has been the "other" of the world's empire, with Hollywood taking American exceptionalism. It unfolds as the stage of identity politics representing all the rest of the world as postcolonial, peripheral, or merely different than Hollywood. However, this "political" model becomes challengeable as the world's ongoing homogenization blurs old boundaries while causing "ethical" deadlocks such as the vicious interlocking between (neo)liberal multiculturalism and fundamentalist terrorism. The notions of subjectivity and society also undergo new crises and changes permeating the entire world beyond the established national or transnational frames of the world. Against this backdrop, world cinema can be reframed not for a world tour of territorialized national cinemas or transnational deterritorialization but a critical remapping of many contemporary films reflecting global phenomena even in localized narrative space. Locality functions here less as the basis of identity, referring to a unique reality that both resists and requires the center's endorsement, than as a contingent springboard for addressing the concrete universality of the world system, including the center. This approach brings a global frame of world cinema.
\end{abstract}

\section{Keywords}

world cinema - national cinema - transnational cinema - global frame 


\section{Mapping Frames of World Cinema ${ }^{1}$}

Today, 'global' is a trendy yet vague word used to modify anything worldwide. Likewise, global cinema is a popular yet unformulated term, often referring to Hollywood blockbusters or simply equated with 'world cinema' as such. Then, it may be vital to ask how world cinema is addressed and then related to global cinema and if they imply different notions. In fact, world cinema has never meant the neutral totality of all films made in the world. Dudley Andrew (2010) even refers it to just one of the historical phases: the cosmopolitan phase $\left(1895^{-1918)}\right.$ when early cinema spread over the world as a new medium, the national phase (-1945) when classical cinema was established in each nation-state, the federated phase (-1968) when film festivals and the French New Wave had international influences, the world cinema phase (-1989) when New Waves hit not only western but largely ignored non-western countries, and the global phase (-present) when 'film' is replaced by digital spectacles that are consumed everywhere simultaneously. Inspired by this periodization, I suggest identifying mapping frames of world cinema as methodological rather than diachronic. World cinema is not gone as a phase but always growing as an audiovisual corpus while differently approached in different historical, geopolitical, cultural conditions. Thus, the following frames are not about world cinema but world cinema studies.

First of all, in the most common and still dominant national frame, world cinema appears as a world map of national cinemas like Italian cinema and Korean cinema. And each national cinema is studied in a broad sense of cinematic ethnography referring to each nation's sociopolitical history, collective memory, and cultural contexts (Nowell-Smith 1997; Hjort and Mackenzie 2000; Hill et al. 2000; Chaudhuri 2005; Badley, Palmer, and Schneider 2006; Vitali and Willemen 2008; Nochimson 2010). The implication is that cinema plays a substantial role in building the imagery of a nation as an imagined community while becoming a national cinema that consists of selected films and their intertextual "coherencies or symptoms" in style, content, narrative, character, background, and so forth (Rosen 1984). However, it is the state, the legitimate agency of/over the nation, that institutionalizes national cinema, just as the government supports it against hegemonic Hollywood in many countries. Likewise, national cinema exists not only culturally as text or art, but also economically for production, exhibition, and consumption. And its unique autonomy emerges in two paradoxical ways as Andrew Higson

1 This essay is a slightly revised excerpt from my "Introduction" to a special issue of Studies in the Humanities (Jeong 2019). 
$(1989 ; 2000)$ suggests: in terms of outward-looking comparison, a national cinema tries to differ from other national cinemas, but often adopting the international standard of Hollywood filmmaking; in terms of inward-looking connection, it represents established national culture to the extent that nationhood, albeit constructed so, is passed off as natural. Nationalism is born in this way, naturalizing national identity and its boundary while (unconsciously) excluding heterogeneous elements. "Nationalist cinema," if not national cinema at large, performs this rightist repression of complexity (Willemen 1994). However, it is such essentialism that constructivism debunks; there is no natural nation but only cultural production, and subjectivity, individual or national, is constituted in the system of power and knowledge (Hayward 2000).

For this reason, the transnational frame emphasizes difference and otherness excluded from national identity and sameness. It could apply to the "federated" and "world cinema" phases as mentioned above on two levels. First, it works to map the New Wave phenomena, aesthetic or political movements of marginal, dissident, artistic filmmaking across different national cinemas, and a kind of leftist 'internationalism' as seen in Third Cinema against neocolonial capitalism (Nowell-Smith 2008; Betz 2009; Guneratne and Dissanayake 2003). Second, recent usages of the term 'transnational' imply the shift of ideological internationalism to deconstructive postcolonialism, but also more broadly, economic formations beyond nations, geopolitical regions sharing a cultural heritage, cosmopolitan nomadism and hybridity, postindustrial and cyber spaces, and so on. For example, European cinema is addressed as a whole from the supranational, translocal EU perspective (Galt 2006; Rivi 2016; Bergfelder 2005). Here or elsewhere, transnational are both the top-down globalization driven by neoliberal corporations and the bottom-up transculturation of counter-hegemonic minorities. While the former concerns the film industry including production and reception, film policies and festivals, transfers and exchanges of national cinemas and capital, the latter concerns identity politics of fragmented groups, polyphonic representations and cultural differences, directors' and characters' migration, diaspora, exile (Ezra and Rowden 2006; Dennison and Lim 2006; Durovicová and Newman 2010; Higbee and Lim 2010; Hjort 2010). In both cases, however, the point is that the transnational does not purely negate the national, but respects yet transcends it. Multilayered heterogeneity within a nation is as important as borderless dynamism among nations in and beyond a region. Arab migrants' 'beur cinema' in France, supranational pan-Chinese cinemas including Hong Kong's and Taiwan's, and such hybrids of Hollywood and local cinemas as Bollywood and Nollywood are all equally transnational beyond Third-Worldism. 
Nonetheless, the 'world' in these frames has been divisive rather than integrative. It has often been approached through the recognition and passion for the 'others' of the world's cinematic empire, Hollywood, which assumes American exceptionalism. American cinema, though central to the cinema world, is not seen as part of world cinema. International film festivals have played the role of screen Olympics to stage all the 'rest' of the world as artistic, auteuristic, peripheral, postcolonial, or simply different from the missing center of Hollywood. Many scholars share this view of world cinema as a political alternative to Hollywood. However, as ever more cinematic 'subalterns' speak out with their distinct identities, this Olympic stadium has been displaying equivalent but exoticized, strange but benign minorities like world music or ethnic cuisine in metropolitan markets. World cinema then appears as a rainbow community of multicultural differences while its neoliberal implications are embedded at the empty center, which is taken by film curators and researchers even unawares. Likewise, this inclusive cosmopolitanism has underlain the representation of the world in Hollywood that opens multiple access points to the world market by incorporating national, racial, cultural diversity (Elsaesser 2012). Consequently, world cinema outside Hollywood and the world in Hollywood cinema share some 'ethical' tendency despite their seemingly 'political' opposition. Both, therefore, reflect the post-political paradigm of globalization-I will explain it later.

To be sure, the Manichean dichotomy between 'bad' normative Hollywood and the 'good' alternative rest neglects their hybridity. But conversely, to view world cinema as only "polycentric" including Hollywood as "just another other" cinema might reinforce the UN-style multiculturalism in "planetary consciousness" when this neutral position is taken as a backlash against the politically charged postcolonial theory (Nagib, Perriam, and Dudrah 2012; Pratt 2010). The thing is that politicized cultural studies and critical 'post-' discourses have been the core of the transnational frame, centering on the old question of identity formation and representation to criticize bias or discrimination and promote diversity or pluralism. This approach is valid insofar as the power hierarchy remains between the First and the Third worlds, the West and the East, and the North and the South (Shohat and Stam 1994; 2003). In this frame, however, new issues regarding today's globalized world and which are more comprehensive or fundamental than cultural identity might not be aptly and deftly detected. For the global milieu of unprecedented trade, traffic, technology, as well as catastrophic risks-political, economic, or environmental-directly condition and impact local life without being necessarily mediated through the national/transnational dyad that is still based on the unit of nation. Indeed, if internationalism or transnationalism derive from 
state-centric discourses, globalization involves "non place-specific processes" that change local places while its central system of neoliberal capitalism enables diverse cultural operations and entails instabilities and inequalities at once (Wagner 2015).

Therefore some 'urgency of now' emerges to update the transnational frame on the new horizon of global-local relations reflected or refracted both 'in and outside' Hollywood, without recourse to 'apolitical polycentrism.' I propose a global frame of world cinema in this context. It brings into relief not territorialized homogeneity or deterritorializing heterogeneity, but the reterritorialization of transnational forces onto the immanent plane of globalization and its antinomies, i.e., a new universality and its cracks. For globalization has reunited a polycentric world into a 'totalized network' that has endless connections and crises we experience more or less universally. This global frame hosts neither a world tour of distinct or even ghettoized national cinemas, nor a transnational display of geopolitical and cultural exchanges, but critical engagement with global phenomena that contemporary films reveal or portray even in localized narrative space.

In my frame, these phenomena largely concern 'systems of inclusion' that generate the neoliberal milieu and multicultural traffic as well as 'symptoms of exclusion' that are generated by the very systems, involving illegal migration, casual labor, and various catastrophes. This conceptual pair epitomizes two phases of the world in the post-Cold War era. The 199os saw the fall of the communist bloc and the incorporation of ideological opponents into a single globe of rainbow communities where liberal democracy and transnational capitalism formed the so-called 'post-historical' zeitgeist. In the 20oos, however, such catastrophes as the 9/11 terror and the 2008 financial meltdown signaled the violent return of the repressed or excluded and viral effects of socioeconomic networking and polarization as inevitable byproducts of glorious globalization. The vicious cycle of terror and war on terror has since been hardly resolvable via traditional politics that is characterized as the struggle and negotiation for dialectic changes among different interest or identity groups within a society. Politics has instead given way to a double ethical stance that the entire global society takes toward its misfits or outsiders, as Jacques Ranciere (2004) argues: the "soft-ethical" tolerance for the victimized 'other' to grant human rights and the "hard-ethical" infinite justice against the fundamentalist 'other' as the "axis of evil" to expel and eradicate. Otherness is thus either liberally absorbed into the global system or monstrously demonized by the very system that wields sovereign power in the name of security and self-defense, often without following proper judicial procedures. In this global age of inclusion and exclusion, both subjectivity and community undergo new crises and changes. I then 
thematically characterize global cinema as reflecting today's globalism with its inconsistency and today's humanity responding to this new condition of life.

\section{Global Cinema of Abjection and Agency}

Global cinema has a typical narrative arc reflecting this new human condition. Main characters die symbolically at the beginning by being lost, cast, detached, or expelled out of their community, often traumatically — on a daily level, it may appear as being abandoned, rejected, suspended, or fired from their family, school, workplace, or institution. This symbolic death makes them the "abject," deprived of their social identity and even homeless, jobless, moneyless. In psychoanalysis, Julia Kristeva (1982) defines the "abject" as what is rejected or excluded from oneself but not yet a separate thing, thus thrown in a state of limbo between subject and object, neither alive nor dead. By extension, there has been growing studies on "social abjection," the suspension of political subjectivity and legal rights (Tyler 2013). Stripped of their membership or citizenship, even human rights, the abject (characters) I just noted are forced to live in the state of "bare life" like animals or homo sacer that can be killed outside the law as Giorgio Agamben (1998) says. The rest of the narrative shows how they survive in this symbolic postmortem state of being. They mostly struggle to rejoin their community and regain their subjectivity, which succeeds or fails toward the end, often at the cost of their biological life. The two deaths, symbolic and real, thus shape the narrative of abjection and redemption. I call it the narrative of double death.

However, the task of the abject is not limited to regaining their 'normal' state. They often take revenge, terrorize those who abjected them, or even destroy their ex-community. But they also make a new relationship or form certain solidarity outside the biopolitical mechanism of abjection. In other words, the abject do not remain victimized once they cultivate 'agency': the causative force to activate actions, the capacity to act for a mission even if effects are uncertain. Agency is thus the abject mode of subjectivity. It is not preformed but performed only at the moment of action, and reperformed through temporary modulation and flexible adaptation to changing circumstances. Agency in this performativity is not predestined toward any lost origin or subservient to the established order. It accounts for the "reassemblage" of subjectivity confronting unpredictable crises in the global age better than the traditional notion of identity. What I call 'abject agency' can then bring, if not a utopian political change, but some ethical alternatives to the inclusion in or exclusion from the global system. 
I propose to critically engage in this global cinema of abjection and agency while drawing our attention to such issues as multiculturalism, fundamentalism, law, violence, catastrophe, community, network, utopia, and gift. Locality functions here not as the root of identification with a unique reality, national or regional, but as a concrete springboard for embodying the universal global system and precarious life in it. Indeed, the narrative of double death pervades global cinema from Hollywood blockbusters and European art films to Middle Eastern dramas and Asian genre films. This is why Hollywood should be viewed as part of world cinema, which in turn should not be featured as marginal or exotic. Likewise, postcolonial emphasis on exilic subjectivity and ethics as in the "accented cinema" (Naficy 2001) could be reviewed in global terms of abjection and agency. Thanks to powerful visuality, world cinema globalizes locality much more vividly than world literature and enables its studies not to be entrapped in the logic of difference and the difficulty of its translation. We could thus 'go global' by recharging identity politics rooted in class, gender, racial differences with a new theorization of global subjectivity and community.

Admittedly, there can be global frames other than mine. Some recent books on world cinema survey it through a specific theoretical lens, for instance, Deleuzian or realist, which offers a kind of global frame beyond the transnational one, not limited to the age of globalization (Martin-Jones 2011; Nagib 2011). Other notable books illuminate contemporary films with heated subjects such as globalization and terror (Chaudhuri 2014; Kapur and Wagner 2013). Moreover, ever more monographs and textbooks include "global" in their (sub) titles, expanding 'global cinema' as a field (Hjort 2005; Galt and Schoonover 2010; Sinha and McSweeney 2012; Costanzo 2014; Stafford 2014). But although the term is mentioned here and there, its nature and scope tend to be somewhat arbitrary or ambiguous like 'world cinema,' involving a random variety of films around the topic of art, memory, genre, or industry. Against this background, I would propose to highlight the thematic superstructure of biopolitical and ethical concerns on the post-political ground of troubled globalization, mapping diverse local films across a vast net of post-199o narrative cinema: both commercial and art films globally circulating in the mainstream market and the festival circuit regardless of genre and style. This scope misses the so-called Fourth Cinema and "non-cinema," mostly indigenous, digital, or DIY-style film practices that are excluded from the institutional field of cinema though globally proliferating — in a sense, the 'abject cinema' per se (Murray 2009; Brown 2018). But conversely, my global frame intends to be efficiently limited to a selection of blockbusters and auteurist films as part of a global cinematic system mirroring the global system as such. This cinematic system 
is, as it were, a matrix of global cinema with unconscious symptoms, political dilemmas and ethical potentialities, which I related to current film authorship (Jeong and Szaniawski 2016). Now, in a consistent setting of agendas, we could navigate around this matrix that includes both global Hollywood directors and global auteurs.

\section{References}

Agamben, Giorgio. 1998. Homo Sacer: Sovereign Power and Bare Life. Translated by Daniel Heller-Roazen . Stanford, CA: Stanford University Press.

Andrew, Dudley. 2010. 'Time Zones and Jetlag: The Flows and Phases of World Cinema'. In World Cinemas, Transnational Perspectives, edited by Nat Durovicová and Kathl Newman , 59-89. New York: Routledge.

Badley, Linda, R. Barton Palmer, and Steven Jay Schneider, eds. 2006. Traditions in World Cinema. New Brunswick, NJ: Rutgers University Press.

Bergfelder, Tim. 2005. 'National, Transnational or Supranational Cinema? Rethinking European Film Studies'. Media, Culture \& Society 27 (3): 315-31.

Betz, Mark. 20og. Beyond the Subtitle: Remapping European Art Cinema. Minneapolis: University of Minnesota Press.

Brown, William. 2018. Non-Cinema: Global Digital Film-Making and the Multitude. Bloomsbury.

Chaudhuri, Shohini. 2005. Contemporary World Cinema: Europe, the Middle East, East Asia and South Asia. Edinburgh: Edinburgh University Press.

Chaudhuri, Shohini. 2014. Cinema of the Dark Side: Atrocity and the Ethics of Film Spectatorship. Edinburgh: Edinburgh University Press.

Costanzo, William V. 2014. World Cinema through Global Genres. Chichester, UK: Wiley-Blackwell.

Dennison, Stephanie, and Song Hwee Lim, eds. 20o6. Remapping World Cinema: Identity, Culture, and Politics in Film. London: Wallflower Press.

Durovicová, Natasa, and Kathleen Newman, eds. 2010. World Cinemas, Transnational Perspectives. New York: Routledge.

Elsaesser, Thomas. 2012. The Persistence of Hollywood. New York: Routledge.

Ezra, Elizabeth, and Terry Rowden. 2006. 'General Introduction: What Is Transnational Cinema?' In Transnational Cinema: The Film Reader, edited by Elizabeth Ezra and Terry Rowden , 1-12. London: Routledge.

Galt, Rosalind. 2006. The New European Cinema: Redrawing the Map. New York: Columbia University Press.

Galt, Rosalind, and Karl Schoonover, eds. 2010. Global Art Cinema: New Theories and Histories. New York: Oxford University Press. 
Guneratne, Anthony R., and Wimal Dissanayake. 2003. Rethinking Third Cinema. New York: Routledge.

Hayward, Susan. 200o. 'Framing National Cinema'. In Cinema and Nation, edited by Mette Hjort and Scott MacKenzie , 88-102. London: Routledge.

Higbee, Will, and Song Hwee Lim. 2010. 'Concepts of Transnational Cinema: Towards a Critical Transnationalism in Film Studies'. Transnational Cinemas 1 (1): 7-21.

Higson, Andrew. 1989. 'The Concept of National Cinema'. Screen 30 (4): 36-46.

Higson, Andrew. 2000. 'The Limiting Imagination of National Cinema'. In Cinema and Nation, edited by Mette Hjort and Scott MacKenzie , 63-74. London: Routledge.

Hill, John, Pamela Church Gibson, Richard Dyer, E. Ann Kaplan, and Paul Willemen, eds. 200o. World Cinema: Critical Approaches. Oxford; New York: Oxford University Press.

Hjort, Mette. 2005. Small Nation, Global Cinema: The New Danish Cinema. Minneapolis: University of Minnesota Press.

Hjort, Mette. 2010. 'On the Plurality of Cinematic Transnationalism'. In World Cinemas, Transnational Perspectives, edited by Nat Durovicová and Kathl Newman , 12-33. New York: Routledge.

Hjort, Mette, and Scott Mackenzie, eds. 20oo. Cinema and Nation. London: Routledge. Jeong, Seung-hoon. 2019. 'Introduction - Global East Asian Cinema: Abjection and Agency'. Studies in the Humanities 44 \& 45 (1-2): ii-xxii.

Jeong, Seung-hoon, and Jeremi Szaniawski, eds. 2016. The Global Auteur: The Politics of Authorship in 21st Century Cinema. New York: Bloomsbury.

Kapur, Jyotsna, and Keith B. Wagner, eds. 2013. Neoliberalism and Global Cinema: Capital, Culture, and Marxist Critique. New York: Routledge.

Kristeva, Julia. 1982. Powers of Horror: An Essay on Abjection. Translated by Leon S. Roudiez . New York: Columbia University Press.

Martin-Jones, David. 2011. Deleuze and World Cinemas. London: Continuum.

Murray, Stuart. 2009. Images of Dignity: Barry Barclay and Fourth Cinema. Honolulu: University of Hawaii Press.

Naficy, Hamid. 2001. An Accented Cinema: Exilic and Diasporic Filmmaking. Princeton, NJ: Princeton University Press.

Nagib, Lúcia. 2011. World Cinema and the Ethics of Realism. New York: Continuum.

Nagib, Lúcia, Christopher Perriam, and Rajinder Kumar Dudrah, eds. 2012. Theorizing World Cinema. London: I.B. Tauris.

Nochimson, Martha P. 2010. World on Film: An Introduction. Chichester, UK: Wiley-Blackwell.

Nowell-Smith, Geoffrey, ed. 1997. The Oxford History of World Cinema. Oxford, UK: Oxford University Press.

Nowell-Smith, Geoffrey. 2008. Making Waves New Cinemas of the 196os. New York: Continuum. 
Pratt, Mary Louise. 2010. Imperial Eyes: Travel Writing and Transculturation. London: Routledge.

Rancière, Jacques. 2004. 'The Ethical Turn of Aesthetics and Politics'. In Aesthetics And Its Discontents, 109-32. Cambridge: Polity Press.

Rivi, Luisa. 2016. European Cinema after 1989: Cultural Identity and Transnational Production. New York: Palgrave Macmillan.

Rosen, Philip. 1984. 'History, Textuality, Nation: Kracauer, Burch and Some Problems in the Study of National Cinemas'. Iris 2 (2): 6o-83.

Shohat, Ella, and Robert Stam. 1994. Unthinking Eurocentrism: Multiculturalism and the Media. London: Routledge.

Shohat, Ella, and Robert Stam, eds. 2003. Multiculturalism, Postcoloniality, and Transnational Media. New Brunswick, NJ: Rutgers University Press.

Sinha, Amresh, and Terence McSweeney, eds. 2012. Millennial Cinema: Memory in Global Film. London: Wallflower Press.

Stafford, Roy. 2014. The Global Film Book. London: Routledge.

Tyler, Imogen. 2013. Revolting Subjects: Social Abjection and Resistance in Neoliberal Britain. London: Zed Books.

Vitali, Valentina, and Paul Willemen, eds. 20o8. Theorising National Cinema. London: British Film Institute.

Wagner, Keith B. 2015. 'Globalizing Discourses: Literature and Film in the Age of Google'. Globalizations 12 (2): 229-43.

Willemen, Paul. 1994. 'The National'. In Looks and Frictions: Essays in Cultural Studies and Film Theory, 206-19. Indiana University Press. 